\title{
Pengaruh Penerapan Sistem Manajemen Mutu terhadap Kualitas Pelaksanaan Kegiatan Operasi dan Pemeliharaan (Studi Kasus: Tugas Pembantuan Operasi dan Pemeliharaan Daerah Irigasi Kedung Asem dan Daerah Irigasi Bodri Provinsi Jawa Tengah)
}

\author{
Mualim Amin \\ Balai Wilayah Sungai Sulawesi IV \\ Direktorat Jenderal Sumber Daya Air \\ Kementerian Pekerjaan Umum dan Perumahan Rakyat \\ Jl. Balai Kota IV No.1 Kendari - Sulawesi Tenggara \\ E-mail: mualimamin@yahoo.com
}

\author{
M. Agung Wibowo \\ Departemen Teknik Sipil, Fakultas Teknik, Universitas Diponegoro \\ Jl.Prof. Soedarto, SH, Tembalang, Semarang 50275 \\ E-mail: agung_wibowo8314423@yahoo.com \\ Pranoto Samto Atmojo \\ Departemen Teknik Sipil, Fakultas Teknik, Universitas Diponegoro \\ Jl.Prof. Soedarto, SH, Tembalang, Semarang 50275 \\ E-mail: pranotosa2001@yahoo.com
}

\begin{abstract}
A decrease in irrigation network performance system operation and maintenance are the impact of the operation management system and irrigation maintenance which does not suitable with the technical demands of the irrigation network design. The purpose of this study is to determine the effect of the application of quality management system in ministry of public works to the quality of the operations and maintenance on the Tasks Operation and Maintenance. The object of the research was in Kedung Asem and Bodri Irrigation Area, it was seen from three variables, namely: (1) the management of resources, (2) the implementation of the activities, (3) measurement, analysis and improvement. Data were obtained from observation andquestionnaire, and then were processed by using descriptive method and linear regression method. The results says that the quality management system in resource management is perceived as good enough category; the implementation activities, measurement, analysis and improvement were perceived good by the respondents. Identification of the quality of the operations and maintenance were also perceived good; further, performance index ratings of irrigation systems are performing well. The results of multiple linear regression equation is $Y=12.883+1,181 X 1+0,449 X 2+1,210 X 3$, the conclusions hypothesis testing shows that the implication of quality management system give positive and significant effect on improving the quality of operations and maintenance work on the Tasks Operation and Maintenance of (DI) Kedung Asem and (DI) Bodri Irrigation Area.
\end{abstract}

Keywords: Irrigation area, Operation and maintenance, Quality management system, The quality of implementation.

\footnotetext{
Abstrak

Penurunan kinerja jaringan irigasi pada sistem operasi dan pemeliharaan merupakan dampak sistem manajemen operasi dan pemeliharaan irigasi yang tidak sesuai dengan tuntutan teknis desain jaringan irigasi. Tujuan penelitian ini untuk mengetahui pengaruh penerapan sistem manajemen mutu Kementerian
} 
Pekerjaan Umum terhadap kualitas pelaksanaan kegiatan operasi dan pemeliharaan pada Tugas Pembantuan Operasi dan Pemeliharaan dengan objek penelitian Daerah Irigasi Kedung Asem dan Daerah irigasi Bodri, dilihat dari tiga variabel, yaitu: (1) pengelolaan sumber daya, (2) penyelenggaraan kegiatan, (3) pengukuran, analisis dan perbaikan. Data diperoleh dari observasi dan kuisioner serta diolah menggunakan metode deskriptif dan metode regresi linier. Hasil identifikasi penerapan sistem manajemen mutu pada pengelolaan sumber daya dipersepsikan kategori cukup baik, penyelenggaraan kegiatan, pengukuran, analisis dan perbaikan dipersepsikan kategori baik oleh responden. Identifikasi kualitas pelaksanaan kegiatan operasi dan pemeliharaan dipersepsikan pada kategori baik dan penilaian indeks kinerja sistem irigasi berkinerja baik. Hasil uji regresi linier berganda diperoleh persamaan $Y=12,883+1,181 X 1+0,449 X 2+1,210 X 3$ dan kesimpulan uji hipotesis menunjukkan bahwa penerapan sistem manajemen mutu berpengaruh positif dan signifikan terhadap peningkatan kualitas pelaksanaan pekerjaan operasi dan pemeliharaan pada Tugas Pembantuan Operasional dan Pemeliharaan Daerah Irigasi (DI) Kedung Asem dan Daerah Irigasi (DI) Bodri.

Kata-kata kunci: Daerah irigasi, Kualitas pelaksanaan, Operasi dan pemeliharaan, Sistem manajemen mutu.

\section{Pendahuluan}

Langkah Pemerintah melalui program besar Nawacita, salah satunya memprioritaskan kebijakan dalam hal irigasi untuk mendukung ketahanan pangan dengan melakukan pembangunan berkelanjutan, meningkatkan distribusi yang dapat dilakukan dalam bentuk meningkatkan keandalan prasarana jaringan irigasi, melaksanakan kebijakan sustainabilitas yakni kebijakan meningkatkan kinerja Operasi dan Pemeliharaan (OP) dengan penambahan tenaga atau sumber daya manusia di bidang Operasi dan Pemeliharaan. Pembangunan yang berkelanjutan dibidang infrastruktur harus disesuaikan dengan peningkatan mutu dan produktifitas kerja.

Penerapan sistem manajemen mutu merupakan upaya peningkatan pelayanan pemerintah kepada masyarakat, sehingga dalam memberikan layanan tersebut pemerintah perlu menyiapkan kerangka sistem manajemen mutu ke arah yang diinginkan sesuai sasaran atau tujuan akhir yang ditetapkan oleh lembaga. Menerapkan sistem manajemen mutu, suatu instansi pemerintah dapat menunjukkan keterbukaan dan akuntabilitasnya kepada masyarakat.

Kementerian Pekerjaan Umum dalam memberikan pelayanan kepada masyarakat terkait peningkatan mutu hasil kegiatan, keterbukaan dan akuntabilitas, telah melaksanakan dan menerapkan sistem manajemen mutu sesuai Peraturan Menteri Pekerjaan Umum Nomor 04/PRT/M/2009 tentang Sistem Manajemen Mutu Kementerian Pekerjaan Umum.

Penerapan sistem manajemen mutu diharapkan dapat mengakomodasi semua sistem yang terkait dengan penjaminan mutu pada seluruh proses kegiatan yang dilaksanakan dan harus dapat menunjukkan peningkatan berkelanjutan dalam unit kerja/unit pelaksana di lingkungan Kementerian Pekerjaan Umum dan Perumahan Rakyat. Sistem Manajemen Mutu Kementerian Pekerjaan Umum dan Perumahan Rakyat mengacu pada persyaratan-persyaratan standar nasional SNI 19-9001-2000 sebagai adopsi pendekatan proses pada saat mengembangkan, menerapkan dan memperbaiki keefektifan sistem manajemen mutu untuk kepuasan pelanggan.

Pembangunan infrastruktur yang dicanangkan pemerintah salah satunya yaitu pembangunan dan pengolahan sumber daya air, terutama pada pengelolaan dan pengembangan irigasi. Pemberian air irigasi dari hulu (up stream) sampai dengan hilir (down stream) memerlukan sarana dan prasarana irigasi yang memadai. Sarana dan prasarana tersebut dapat berupa bendungan, saluran primer dan sekunder, kotak bagi, bangunan-bangunan ukur, dan saluran tersier. Pemenuhan sarana dan prasarana tersebut harus diwujudkan untuk mendukung keberlanjutan sistem irigasi yang sangat penting dan strategis dalam rangka penyediaan air untuk pertanian.

Kegiatan operasi dan pemeliharaan irigasi adalah kegiatan pengaturan air dan jaringan irigasi yang meliputi penyediaan, pembagiaan, pemberiaan, penggunaan dan pembuangannya, termasuk usaha mempertahankan kondisi jaringan agar tetap berfungsi dengan baik. Kerusakan atau terganggunya salah satu bangunan irigasi akan mempengaruhi kinerja sistem yang ada, sehingga mengakibatkan efisiensi dan efektifitas irigasi menjadi menurun. Apabila kondisi ini dibiarkan terus dan tidak segera diatasi, maka akan berdampak terhadap penurunan produksi pertanian, dan berimplikasi negatif terhadap kondisi pendapatan petani dan keadaan sosial, ekonomi disekitar lokasi (Direktorat Pengelolaan Air, 2010). 
Pengukuran kinerja jaringan irigasi pada sistem operasi dan pemeliharaan dapat dilakukan dengan menganalisa sistem manajemen operasi dan pemeliharaan, dan mengevaluasi proses perencanaan dan pelaksanaan pekerjaan untuk mengetahui kualitas pekerjaan yang telah dilaksanakan pada kegiatan operasi dan pemeliharaan. Penerapan sistem manajemen mutu pada kegiatan operasi dan pemeliharaan dapat membantu manajemen organisasi dalam menguatkan mutu kinerjanya untuk meningkatkan efisiensi dan produktifitas kerja sehingga dapat memperbaiki kinerja dan budaya kerja yang sehat. Program peningkatan kualitas yang baik harus berbasis pada proses dan tidak hanya mengandalkan pada inspeksi akhir (Oakland, 1997).

Studi tentang penerapan sistem manajemen mutu Kementerian Pekerjaan Umum yang dikaitkan dengan kualitas pelaksanaan kegiatan operasi dan pemeliharaan masih terbatas, sehingga menarik untuk diketahui apakah penerapan sistem manajemen mutu berpengaruh terhadap kualitas pekerjaan operasi dan pemeliharaan yang ada pada Tugas Pembantuan Operasi dan Pemeliharaan (TP-OP).

Objek penelitian Daerah Irigasi Kedung Asem dan daerah Irigasi Bodri yang merupakan tugas pembantuan operasi dan pemeliharaan. Kedua Daerah irigasi tersebut berada di wilayah kerja Dinas Pengelolaan Sumber Daya Air (Dinas PSDA) Provinsi Jawa Tengah, dan pengelolaannya dilaksanakan oleh Balai Pengelolaan Sumber Daya Air Jragung Tuntang. Setelah adanya penerapan sistem manajemen mutu Kementerian Pekerjaan Umum D.I. Kedung Asem dan D.I. Bodri belum pernah dilakukan penelitian mengenai dampak penerapan sistem manajemen mutu terhadap kualitas pelaksanaan pekerjaan operasi dan pemeliharaan.

Hipotesis pada penelitian ini yaitu penerapan sistem manajemen mutu Kementerian Pekerjaan Umum dan Perumahan Rakyat berpengaruh positif terhadap peningkatan kualitas pelaksanaan pekerjaan operasi dan pemeliharaan pada tugas pembantuan operasional dan pemeliharaan Daerah Irigasi (DI) Kedung Asem dan D.I. Bodri.

Tujuan penelitian ini untuk mengetahui pengaruh penerapan sistem manajemen mutu Kementerian Pekerjaan Umum terhadap kualitas pelaksanaan kegiatan operasi dan pemeliharaan pada tugas pembantuan operasi dan pemeliharaan dengan objek penelitian Daerah Irigasi Kedung Asem dan D.I. Bodri, dilihat dari tiga variabel, yaitu:

1. Pengelolaan sumber daya,

2. Penyelenggaraan kegiatan,

3. Pengukuran, analisis dan perbaikan.

\section{Bahan dan Metode}

Metode yang akan digunakan dalam penelitian ini merupakan Pengujian Hipotesis Asosiatif. Pengertian Hipotesis Asosiatif adalah suatu pernyataan yang menunjukkan dugaan tentang hubungan antara 2 (dua) variabel atau lebih. Analisa data digunakan untuk menjelaskan hubungan kausal antara variabel-variabel melalui pengujian hipotesa.

\section{Populasi}

Responden dalam penelitian ini merupakan sumber daya manusia yang berkompeten dan bertanggungjawab terhadap kegiatan operasi dan pemeliharaan, yang terdiri dari Pejabat Pembuat Komitmen (PPK), Pelaksana Teknik Pekerjaan Operasi dan Pemeliharaan, Pelaksana Mutu Operasi dan Pemeliharaan, Petugas Audit Mutu Internal, dan semua yang terkait maupun terlibat langsung pada kegiatan operasi dan pemeliharaan pada D.I. Kedung Asem dan D.I. sebagai lokasi penelitian.

\section{Diagram alir penelitian}

Tahapan-tahapan dalam penelitian ini, dapat dilihat pada diagram alir penelitian Gambar 1 .

\section{Definisi operasional variabel}

Definisi operasional variabel adalah unsur penelitian yang memberitahukan bagaimana cara mengukur suatu variabel penelitian atau dapat dikatakan semacam petunjuk pelaksana mengukur suatu variabel (Zainuddin dalam Novitasari, 2003). Definis operasional variabel berisi indikatorindikator suatu variabel, yang memungkinkan peneliti mengumpul data yang relevan untuk variabel tersebut.

\section{Variabel independent}

Variabel bebas pada penelitian ini merupakan variabel yang terkait dengan penerapan sistem manajemen mutu sesuai Peraturan Menteri Pekerjaan Umum No. 04/PRT/M/2009 tentang Sistem Manajemen Mutu, yaitu: 

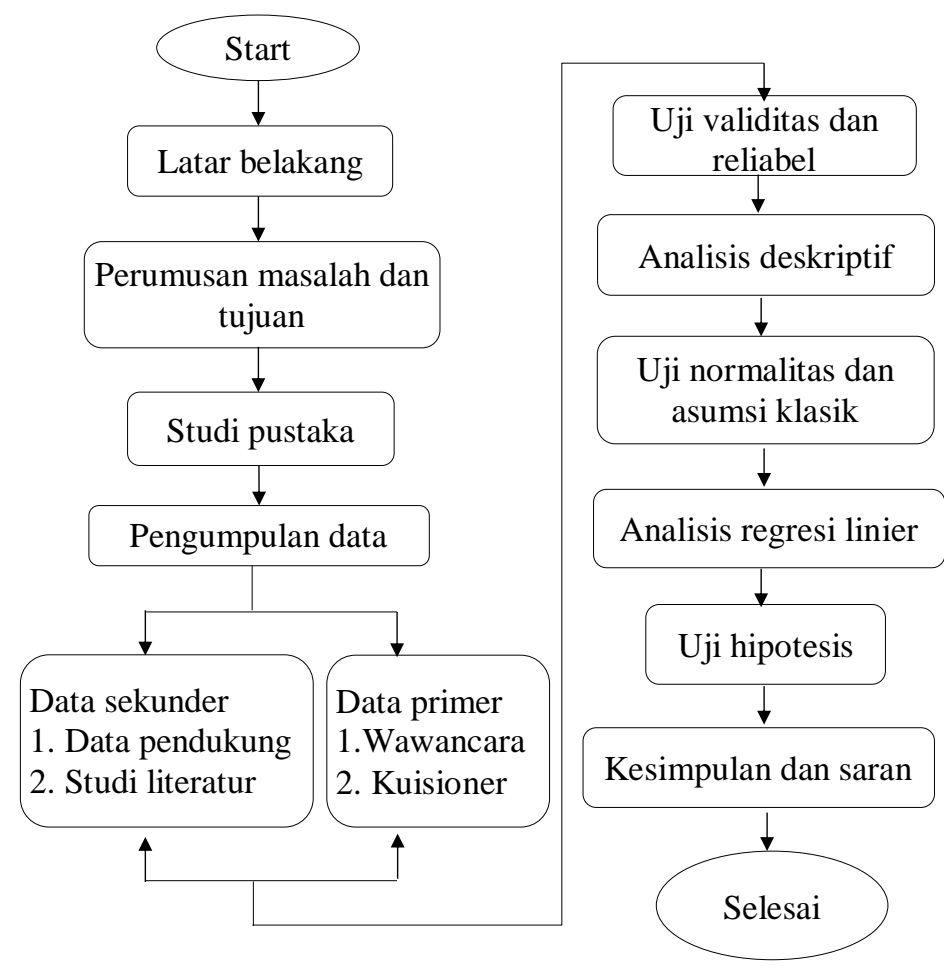

Gambar 1. Diagram alir penelitian

Pengelolaan sumber daya $\left(\mathrm{X}_{1}\right)$

Pengelolaan sumber daya merupakan aspek penting dalam penerapan sistem manajemen mutu Kementerian Pekejaan Umum karena terkait dengan jaminan ketersediaan sumber daya yang diperlukan untuk merencanakan, mengelola, menerapkan, memelihara, dan mengembangkan sistem manajemen mutu di lingkungan Kementerian Pekerjaan Umum dan meningkatkan kepuasan pelanggan. Indikator variabel pengelolaan sumber daya terdiri dari:

1. Penyediaan anggaran,

2. Penyediaan sumber daya manusia,

3. Prsarana dan sarana,

4. lingkungan kerja.

\section{Penyelenggaraan kegiatan $\left(\mathrm{X}_{2}\right)$}

Penyelenggaran kegiatan sistem manajemen mutu adalah suatu upaya organisasi dalam menyiapkan suatu sistem manajemen yang dapat mengatur segala kegiatan yang ada dalam organisasi untuk memenuhi kebutuhan pelanggan dengan sebaikbaiknya pada setiap usaha. Indikator variabel penyelenggaraan kegiatan sistem manajemen mutu $\left(\mathrm{X}_{2}\right)$ terdiri dari:

1. Rencana mutu,

2. Proses yang berkaitan dengan pelanggan,

3. Evaluasi persyaratan berkaitan dengan hasil pekerjaan,

4. Desain dan pengembangan,

5. Sosialisasi/pelatihan/bimbingan teknis,
6. Pengadaan,

7. Proses dan pelaksanaan kegiatan,

8. Pengendalian sarana monitoring dan pengukuran.

Pengukuran, analisis dan perbaikan $\left(\mathrm{X}_{3}\right)$

Pengukuran, analisis dan perbaikan merupakan bagian untuk memperagakan atau memberikan bukti kesesuaian proses dan hasil pekerjaan (hasil kegiatan) terhadap ketentuan standar dan persyaratan yang berlaku, serta memberikan efektifitas dan efesiensi perbaikan dari sistem manajemen mutu secara berkelanjutan. Indikator dari variabel pengukuran, analisis dan perbaikan terdiri dari:

1. Monitoring dan pengukuran,

2. Pengendalian hasil pekerjaan tidak sesuai,

3. Analisis data,

4. Perbaikan.

\section{Variabel dependent}

Dalam penelitian ini terdapat satu variabel dependent (Y), yaitu kualitas pelaksanaan kegiatan operasi dan pemeliharaan pada Satuan Kerja Perangkat Daerah (SKPD) Tugas Pembantuan Operasi dan Pemeliharaan. Pengukuran kualitas pelaksanaan kegiatan operasi dan pemeliharaan pada penelitian ini dilakukan sesuai Peraturan Menteri Pekerjaan Umum No. 33/PRT/M/2015 tentang Tugas Pembantuan Operasi dan Pemeliharaan. Indikator variabel kualitas 
pelaksanaan kegiatan operasi dan pemeliharaan terdiri dari:

1. Rancangan manajemen pelaksanaan,

2. Penyiapan administrasi,

3. Penyiapan rencana kerja,

4. Pelaksanaan konsultasi kegiatan,

5. Koordinasi dengan unit perencana dan pengawasan teknik,

6. Penyebarluasan informasi atau sosialisasi kegiatan,

7. Kesesuaian pekerjaan lapangan,

8. Penyusunan metode pelaksanaan dan pengawasan,

9. Pembayaran sesuai batas waktu,

10. Perbandingan petunjuk operasional kegiatan (pok) dengan keadaan lapangan,

11.Penyampaian laporan kemajuan pelaksanaan pekerjaan,

12. Pelaporan penyerapan dana,

13. Petugas monitoring pelaksanaan,

14. Pembentukan panitia penerimaan pekerjaan,

15. Pengupayaan pemeliharaan hasil pekerjaan,

16. Peraturan tentang Penyerahan Pekerjaan.

\section{Model hubungan variabel}

Berdasarkan hasil uraian di atas, model hubungan variabel dapat dilihat pada Gambar 2.

\section{Pengukuran pencapaian standar pelayanan minimal}

Perhitungan persentase target pencapaian standar pelayanan minimal penyediaan air irigasi untuk pertanian dapat dihitung dengan persamaan 1 .

\section{Analisis deskriptif distribusi frekuensi}

Metode analisis deskriptif merupakan metode yang digunakan untuk menganalisis data data yang tersedia dan diolah sehingga diperoleh gambaran yang jelas mengenai fakta-fakta dan hubungan antar fenomena yang diteliti.

\section{Analisis regresi linier}

Model analisis yang digunakan adalah model analisis regresi linier berganda. Model ini digunakan untuk mengetahui pengaruh variabel bebas terhadap variabel terikat dengan persamaan 2 .

$\mathrm{Y}=\mathrm{a}+\mathrm{b}_{1} \mathrm{X}_{1}+\mathrm{b}_{2} \mathrm{X}_{2}+\mathrm{b}_{3} \mathrm{X}_{3}+\mathrm{e}$

dimana:

$\mathrm{Y} \quad=$ Kualitas pelaksanaan kegiatan operasi dan pemeliharaan

a $\quad=$ Konstanta

$\mathrm{X}_{1} \quad=$ Pengelolaan sumber daya

$\mathrm{X}_{2} \quad=$ Penyelenggaraan kegiatan

$\mathrm{X}_{3} \quad=$ Pengukuran, analisis dan perbaikan

b1,2,3 = Koefisien regresi variabel $\mathrm{X}_{1}, \mathrm{X}_{2}, \mathrm{X}_{3}$

e $=$ error

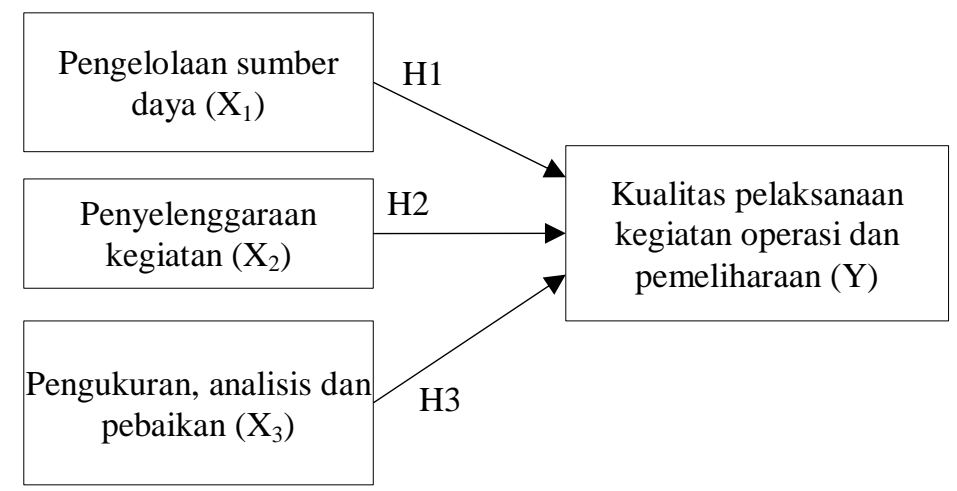

Gambar 2. Model hubungan variabel

SPM Keandalan ketersediaan air irigasi $=\frac{\sum \text { Ketersediaa air irigasi (liter/detik) pada setiap musim tanam }}{\sum \text { kebutuhan air irigasi (liter/detik) berdasarkan rencana tanam }}$

dimana:

- Ketersediaan air irigasi (lt/det) pada setiap musim tanam adalah jumlah air irigasi yang dialirkan selama musim tanam pada suatu daerah irigasi yang sudah ada yang dihitung berdasarkan kemampuan saluran dan bangunan serta dinyatakan dalam lt/det.

- Kebutuhan air irigasi (lt/det) berdasarkan rencana tata tanam adalah jumlah air irigasi yang dihitung dan akan dialirkan berdasarkan rencana tata tanam yang telah ditetapkan pada suatu daerah irigasi yang sudah ada dan dinyatakan dalam lt/det. 
Model regresi linier berganda yang dipakai dalam penelitian ini harus memenuhi syarat uji normalitas dan uji asumsi klasik yaitu uji multikolonieritas, uji autokorelasi dan uji heterokedastisitas.

\section{Hasil dan Pembahasan}

\section{Karakteristik responden}

Responden dalam penelitian ini diklasifikasikan berdasarkan pendidikan, usia responden, jabatan yang dilaksanakan, lama bekerja. Karaktersistik responden dapat dilhat pada tabel di bawah ini:

Tabel 1. Karektersitik responden

\begin{tabular}{ccc}
\hline Tingkat penidikan & Frekuensi & Persentase (\%) \\
\hline S2 & 2 & 10 \\
S1 & 4 & 20 \\
SMA & 4 & 70 \\
\hline Usia responden & Frekuensi & Persentase (\%) \\
\hline$<25$ Tahun & 0 & 0 \\
26-35 Tahun & 2 & 10 \\
36 - 45 Tahun & 6 & 30 \\
$>45$ Tahun & 12 & 60 \\
\hline Tingkat jabatan & Frekuensi & Persentase (\%) \\
\hline Pendayagunaan dan & 2 & 10 \\
Pengamanan & & \\
Pelaksana Teknik & 2 & 10 \\
Petugas Mutu & 2 & 10 \\
Petugas Audit Mutu & 2 & 10 \\
Pelaksana Administrasi & 2 & 10 \\
Pengawas Lapangan & 10 & 50 \\
\hline Lama bekerja & Frekuensi & Persentase (\%) \\
\hline$>5$ Tahun & 0 & 0 \\
5 - 10 Tahun & 2 & 10 \\
11 - 20 Tahun & 8 & 40 \\
$>$ 20 Tahun & 10 & 50
\end{tabular}

Berdasarkan Tabel 1 di atas, terlihat bahwa berdasarkan tingkat pendidikan, responden paling banyak tingkat pendidikan setara SMA sebanyak 14 orang atau $70 \%$. Data responden berdasarkan usia, responden paling banyak berusia pada kisaran $>45$ tahun sebanyak 12 orang atau $60 \%$. Data responden berdasarkan jabatan responden, sebagian besar adalah Pengawas Lapangan paling banyak sebanyak 10 orang atau 50\%. Data responden berdasarkan lama bekerja, responden lama bekerja pada kisaran $>20$ tahun sebanyak 10 orang atau 50. Jika dilihat dari tingkat pendidikan mayoritas setara SMA tetapi didukung dengan pengalaman kerja $>20$ tahun sehingga dapat mendukung dan membantu untuk mengisi kuisioner dengan baik.

\section{Uji validitas}

Uji validitas kuesioner dengan metode Corrected item-total correlations dengan menggunakan Pearson Correlation. Nilai koefisien korelasi (r) minimum yang dianggap masih memenuhi syarat validitas kuesioner yaitu $r>0.3$. Valid tidaknya suatu item instrumen dapat diketahui dengan membandingkan indeks korelasi product moment pearson dengan level of significant 5\% terhadap nilai korelasinya. Bila signifikansi hasil korelasi lebih kecil dari 0,05 maka dinyatakan valid dan sebaliknya jika hasil korelasinya lebih besar dari 0,05 maka dinyatakan tidak valid (Sugiyono, 2007).

Hasil uji validitas masing-masing variabel independent dan dependent dapat dilihat pada Tabel 2.

Tabel 2. Hasil uji validitas indikator variabel independent

\begin{tabular}{llccc}
\hline Variasi & \multicolumn{1}{c}{ Indikator } & $\begin{array}{c}\text { Koefisien } \\
\text { korelasi }\end{array}$ & Sig. & Ket. \\
\hline \multirow{4}{*}{$\left(\mathrm{X}_{1}\right)$} & Penyediaan dana & 0,863 & 0,000 & Valid \\
& Sumber daya manusia & 0,774 & 0,000 & Valid \\
& Prasarana dan sarana & 0,715 & 0,000 & Valid \\
& Lingkungan kerja & 0,445 & 0,049 & Valid \\
\hline \multirow{4}{*}{ Rencana mutu } & 0,840 & 0,000 & Valid \\
& Proses yang berkaitan dengan pelanggan & 0,629 & 0,003 & Valid \\
& Evaluasi persyaratan berkaitan dengan hasil pekerjaan & 0,629 & 0,003 & Valid \\
& Desain dan pengembangan & 0,893 & 0,000 & Valid \\
& Sosialisasi/pelatihan/bimbingan teknis & 0,568 & 0,009 & Valid \\
& Pengadaan & 0,629 & 0,003 & Valid \\
& Proses dan pelaksanaan kegiatan & 0,453 & 0,047 & Valid \\
& Pengendalian sarana monitoring dan pengukuran & 0,766 & 0,000 & Valid \\
\hline \multirow{5}{*}{$\left(\mathrm{X}_{3}\right)$} & Monitoring dan pengukuran & 0,916 & 0,000 & Valid \\
& Pengendalian hasil pekerjaan tidak sesuai & 0,520 & 0,000 & Valid \\
& Analisis data & 0,916 & 0,000 & Valid \\
& Perbaikan & 0,476 & 0,000 & Valid \\
\hline
\end{tabular}


Tabel 3. Hasil uji validitas indikator variabel dependent

\begin{tabular}{|c|c|c|c|c|}
\hline Variasi & Indikator & $\begin{array}{c}\text { Koef. } \\
\text { korelasi }\end{array}$ & Sig. & Ket. \\
\hline \multirow{16}{*}{$(\mathrm{Y})$} & Rancangan manajemen pelaksanaan & 0,618 & 0,004 & Valid \\
\hline & Penyiapan administrasi & 0,661 & 0,002 & Valid \\
\hline & Penyiapan rencana kerja & 0,450 & 0,042 & Valid \\
\hline & Pelaksanaan konsultasi kegiatan & 0,466 & 0,038 & Valid \\
\hline & Koordinasi dengan unit perencana dan pengawasan teknik & 0,618 & 0,004 & Valid \\
\hline & Penyebarluasan informasi atau sosialisasi kegiatan & 0,476 & 0,032 & Valid \\
\hline & Kesesuaian pekerjaan lapangan & 0,689 & 0,001 & Valid \\
\hline & Penyusunan metode pelaksanaan dan pengawasan & 0,878 & 0,000 & Valid \\
\hline & Pembayaran sesuai batas waktu & 0,714 & 0,000 & Valid \\
\hline & Perbandingan petunjuk operasional kegiatan (POK) dengan keadaan lapangan & 0,488 & 0,029 & Valid \\
\hline & Penyampaian laporan kemajuan pelaksanaan pekerjaan & 0,724 & 0,000 & Valid \\
\hline & Pelaporan penyerapan dana & 0,784 & 0,000 & Valid \\
\hline & Petugas monitoring pelaksanaan & 0,759 & 0,000 & Valid \\
\hline & Pembentukan panitia penerimaan pekerjaan & 0,697 & 0,001 & Valid \\
\hline & Pengupayaan pemeliharaan hasil pekerjaan & 0,776 & 0,000 & Valid \\
\hline & Peraturan tentang penyerahan pekerjaan & 0,994 & 0,000 & Valid \\
\hline
\end{tabular}

Berdasar pada Tabel 2, menunjukkan bahwa indikator masing-masing variabel mempunyai nilai koefisien korelasi, $r>0,30$ dan nilai signifikansi $r$ tersebut $<0,05$. Hal ini menunjukkan bahwa variabel pengelolaan sumber daya $\left(\mathrm{X}_{1}\right)$, penyelenggaraan kegiatan $\left(\mathrm{X}_{2}\right)$, pengukuran, analisis dan perbaikan $\left(\mathrm{X}_{3}\right)$ dinyatakan valid.

Berdasarkan Tabel 3 di atas, menunjukkan bahwa indikator variabel mempunyai nilai koefisien korelasi, $r>0,30$ dan nilai signifikansi $r$ tersebut $<0,05$. Hal ini menunjukkan bahwa variabel kualitas pelaksanaan kegiatan operasi dan pemeliharaan $(\mathrm{Y})$ dinyatakan valid.

\section{Uji reliabilitas}

Uji keandalan (reliabilitas) digunakan untuk menguji kekonstanan dan ketepatan hasil pengukuran kuisioner yang erat hubungannya dengan masalah kepercayaan (Nazir, 1999). Suatu taraf tes dikatakan mempunyai kepercayaan bila tes tersebut memberikan hasil yang tepat.

Apabila Alpha Cronbach $(\alpha)$ lebih besar dari 0,60 maka data penelitian diangap cukup baik dan reliabel untuk digunakan sebagai input dalam proses penganalisaan data guna menguji hipotesis penelitian (Maholtra, 1995).

Berdasarkan Tabel 4 di atas, menunjukkan bahwa variabel pengelolaan sumber daya $\left(\mathrm{X}_{1}\right)$, penyelenggaraan kegiatan $\left(X_{2}\right)$, pengukuran, analisis dan perbaikan $\left(\mathrm{X}_{3}\right)$ dan kualitas pelaksanaan kegiatan operasi dan pemeliharaan (Y) mempunyai nilai koefisien alpha cronbach $>0,60$. Hal ini menunjukkan bahwa indikator masing-masing variabel dinyatakan realiabel (handal).

Tabel 4. Hasil uji reliabilitas

\begin{tabular}{lcc}
\hline \multicolumn{1}{c}{ Variabel } & $\begin{array}{c}\text { Koefisien } \\
\text { alpha } \\
\text { cronbach }\end{array}$ & Kesimpulan \\
\hline $\begin{array}{l}\text { Pengelolaan sumber } \\
\text { daya }\left(\mathrm{x}_{1}\right)\end{array}$ & 0,752 & Reliabel \\
$\begin{array}{l}\text { Penyelenggaraan } \\
\text { kegiatan }\left(\mathrm{x}_{2}\right)\end{array}$ & 0,815 & Reliabel \\
$\begin{array}{l}\text { Pengukuran, analisis } \\
\text { dan perbaikan }\left(\mathrm{x}_{3}\right)\end{array}$ & 0,663 & Reliabel \\
$\begin{array}{l}\text { Kualitas pelaksnaan } \\
\text { kegiatan operasi dan } \\
\text { pemeliharaan (y) }\end{array}$ & 0,917 & Reliabel \\
\hline
\end{tabular}

\section{Analisis deskriptif distribusi frekuensi}

Tujuan dari deskriptif tentang masing-masing indikator dari variabel penelitian adalah untuk mengetahui bagaimana pemusatan dan penyebaran persepsi responden terhadap indikator-indikator tersebut. Penilaian persepsi responden terhadap penerapan sistem manajemen mutu meliputi variabel pengelolaan sumber daya $\left(\mathrm{X}_{1}\right)$, penyelenggaraan kegiatan $\left(\mathrm{X}_{2}\right)$, pengukuran, analisis dan perbaikan $\left(\mathrm{X}_{3}\right)$. Sedangkan untuk kualitas pelaksanaan kegiatan operasi dan pemeliharaan merupakan variabel $(\mathrm{Y})$.

Hasil identifikasi penerapan sistem manajemen mutu pada tugas pembantuan operasi dan pemeliharaan D.I. Kedung Asem dan D.I. Bodri, meliputi penilaian responden terhadap indikator variabel pengelolaan sumber daya $\left(\mathrm{X}_{1}\right)$ yang dipersepsikan pada kategori cukup baik, variabel penyelenggaraan kegiatan $\left(\mathrm{X}_{2}\right)$, dan variabel 
pengukuran, analisis dan perbaikan $\left(\mathrm{X}_{3}\right)$ dipersepsikan pada kategori baik, berdasarkan jawaban responden pada indikator variabel. Variabel pengelolaan sumber daya $\left(\mathrm{X}_{1}\right)$ masih memiliki persepsi yang rendah dari responden bila dibandingkan penilaian responden terhadap indikator variabel penyelenggaraan kegiatan $\left(\mathrm{X}_{2}\right)$, dan variabel pengukuran, analisis dan perbaikan $\left(\mathrm{X}_{3}\right)$. Hal ini menunjukkan bahwa pengelolaan sumber daya sistem manajemen mutu masih perlu ditingkatkan pada indikator penyediaan anggaran, kemampuan sumber daya manusia melalui pelatihan, ketersediaan prasarana dan sarana seperti gedung, ruang kerja, peralatan, transportasi yang dibutuhkan, dan ketersediaan lingkungan kerja sesuai dengan persyaratan mutu yang terkait persyaratan keamanan, kesehatan, keselamatan dan kenyamanan.

Hasil identifikasi kualitas pelaksanaan kegiatan operasi dan pemeliharaan pada tugas pembantuan operasi dan pemeliharaan D.I. Kedung Asem dan D.I. Bodri dipersepsikan pada kategori baik berdasarkan jawaban responden pada indikator variabel. Penilaian responden terhadap indikator perbandingan petunjuk operasional kegiatan dengan keadaan lapangan masih memiliki persepsi yang rendah dari responden bila dibandingkan penilaian responden terhadap indikator variabel lainnya. Indikator penyiapan rencana kerja dan sosialisasi kegiatan dipersepsikan pada kategori baik dengan nilai rata-rata persepsi yang tinggi.

\section{Mengukur pencapaian standar pelayanan minimal}

Hasil perhitungan persentase pencapaian standar pelayanan minimal Daerah Irigasi Kedung Asem $71,21 \%$ dan Daerah Irigasi Bodri 71,42\%. Berdasarkan hasil pencapaian presentase target pencapaian standar pelayanan minimal penyediaan air irigasi untuk pertanian dan dihubungkan ke penentuan persentase indeks kinerja sistem irigasi menyatakan bahwa D.I. Kedung Asem dan D.I. Bodri berkinerja baik.

Indeks kinerja sistem irigasi menggambarkan kinerja jaringan irigasi berdasarkan standar pelayanan minimal. Hasil indeks kinerja sistem irigasi setelah dihubungkan dengan hasil analisis deskriptif distrbusi frekuensi variabel kualitas pelaksanaan kegiatan operasi dan pemeliharaan (Y), menunjukkan kesesuaian, bahwa kualitas pelaksanaan kegiatan operasi dan pemeliharaan tugas pembantuan operasi dan pemeliharaan (TPOP) D.I. Kedung Asem dan D.I. Bodri telah dipersepsikan pada kategori baik dan jaringan irigasi yang ada berkinerja baik.

Tabel 5. Indeks kinerja sistem irigasi (Peraturan Menteri Pekerjaan Umum No. 32 Tahun 2007)

\begin{tabular}{cc}
\hline Persentase & Kinerja \\
\hline $80-100 \%$ & Kinerja sangat baik \\
$70-79 \%$ & Kinerja baik \\
$55-69 \%$ & $\begin{array}{c}\text { Kinerja kurang dan perlu } \\
\text { perhatian } \\
<55 \%\end{array}$ \\
& $\begin{array}{c}\text { Kinerja jelek dan perlu } \\
\text { perhatian }\end{array}$ \\
\hline
\end{tabular}

\section{Uji normalitas}

Uji statistik yang digunakan untuk uji normalitas data dalam penelitian ini adalah uji normalitas atau sampel Kolmogorov-Smirnov. Hasil analisis ini kemudian dibandingkan dengan nilai kritisnya.

Pedoman pengambilan keputusan:

- Angka signifikansi (Sig) $>\alpha=0,05$ maka data berdistribusi normal

- Angka signifikansi (Sig) $<\alpha=0,05$ maka data tidak berdistribusi normal

Berdasarkan hasil uji normalitas, bahwa variabel dependent yaitu kualitas pelaksanaan kegiatan operasi dan pemeliharaan (Y) memiliki signifikansi > 0,05, hal ini menggambarkan bahwa variabel tersebut berdistribusi normal. Untuk variabel independent pengelolaan sumber daya $\left(\mathrm{X}_{1}\right)$, penyelenggaraan kegiatan $\left(\mathrm{X}_{2}\right)$, pengukuran, analisis dan perbaikan $\left(\mathrm{X}_{3}\right)$ tingkat signifikansi $>0,05$ hal ini menggambarkan bahwa semua variabel independent berdistribusi normal.

\section{Analisis uji asumsi klasik}

Berdasarkan hasil uji multikolinearitas yang sudah dilakukan, tidak terdapat kolinier yang berarti dalam hasil regresi untuk model sampel secara keseluruhan (full sample) atau dengan kata lain model regresi terhindar dari masalah multikolinieritas.

Hasil Uji autokorelasi dilakukan dengan menghitung Durbin Watson dapat disimpulkan bahwa tidak ada autokorelasi positif atau negatif. Uji heteroskedastisitas dilakukan dengan menggunakan uji Glejser untuk mengetahui apakah model regresi mengalami masalah heterokedastisitas atau tidak. Berdasarkan hasil uji Glejser dapat disimpulkan bahwa data tersebut bersifat homokedastis. 
Tabel 6. Hasil uji regresi linier

\begin{tabular}{lrrrrr}
\hline \multirow{2}{*}{ Model } & \multicolumn{2}{c}{ Unstandardized coefficients } & Standardize & \multirow{2}{*}{ t } & \multirow{2}{*}{ Sig. } \\
\cline { 2 - 4 } & \multicolumn{1}{c}{ B } & Std.Err & Beta & & \\
\hline Constant) & 12,883 & 5,406 & & 2,383 & 0,030 \\
Pengelolaan $\left(\mathrm{X}_{1}\right)$ & 1,181 & 0,461 & 0,293 & 2,559 & 0,021 \\
Penyelenggaraan $\left(\mathrm{X}_{2}\right)$ & 0,449 & 0,210 & 0,272 & 2,139 & 0,048 \\
Pengukuran $\left(\mathrm{X}_{3}\right)$ & 1,210 & 0,273 & 0,547 & 4,429 & 0,000 \\
\hline
\end{tabular}

\section{Analisis regresi linier}

Untuk mengetahui pengaruh penerapan sistem manajemen mutu terhadap kualitas pelaksanaan kegiatan operasi dan pemeliharaan dapat diuji statistik dengan menggunakan cara analisis regresi linier berganda.

Hasil uji analisis regresi linier berganda diperoleh koefisien masing-masing variabel dan dapat disusun persamaan sebagai berikut:

$\mathrm{Y}=12,883+1,181 \mathrm{X}_{1}+0,449 \mathrm{X}_{2}+1,210 \mathrm{X}_{3} \ldots$

Dari persamaan model dan hasil regresi di atas, dapat diuraikan hal-hal sebagai berikut:

\section{Konstanta}

Nilai konstanta menunjukkan nilai sebesar 12,883 artinya jika variabel pengelolaan sumber daya $\left(\mathrm{X}_{1}\right)$, penyelenggaraan kegiatan $\left(\mathrm{X}_{2}\right)$, pengukuran, analisis dan perbaikan $\left(\mathrm{X}_{3}\right)$ bernilai nol maka nilai variabel kualitas pelaksanaan kegiatan operasi dan pemeliharaan (Y) sebesar 12,833 sesuai dengan besaran konstanta. Dalam kata lain bahwa nilai kualitas pelaksanaan operasi dan pemeliharaan tanpa pengelolaan sumber daya, penyelenggaraan kegiatan, pengukuran, analisis dan perbaikan sistem manajemen mutu yang baik, nilai kualitas pelaksanaan kegiatan operasi dan pemeliharaan adalah $12,833 \%$ yang dipengaruhi oleh variabel lain dari model ini.

Variabel pengelolaan sumber daya $\left(\mathrm{X}_{1}\right)$

Nilai koefisien regresi variabel $\mathrm{X}_{1}$ menunjukkan nilai sebesar 1,181 artinya bahwa setiap kenaikan variabel $\mathrm{X}_{1}$ sebesar $1 \%$ maka variabel $\mathrm{Y}$ akan naik sebesar $1,181 \%$ dengan asumsi variabel bebas yang lain dari model regresi adalah tetap. Penyediaan anggaran untuk penerapan sistem manajemen mutu, pelatihan untuk sumber daya manusia, penyediaan prasarana dan sarana, kualitas lingkungan kerja mengalami peningkatan sebesar $10 \%$ maka kualitas pelaksanaan kegiatan operasi dan pemeliharaan mengalami peningkatan sebesar $11,81 \%$ dan sebaliknya, penurunan pada penyediaan anggaran, pelatihan untuk sumber daya manusia, penyediaan prasarana dan sarana, kualitas lingkungan kerja sebesar $10 \%$ maka kualitas pelaksanaan kegiatan operasi dan pemeliharaan akan mengalami penurunan sebesar $11,81 \%$.

Variabel penyelenggaraan kegiatan $\left(\mathrm{X}_{2}\right)$

Nilai koefisien regresi variabel $\mathrm{X}_{2}$ menunjukkan nilai sebesar 0,449 artinya bahwa setiap kenaikan variabel $\mathrm{X}_{2}$ sebesar $1 \%$ maka variabel $\mathrm{Y}$ akan naik sebesar $0,449 \%$ dengan asumsi variabel bebas yang lain dari model regresi adalah tetap. Penyediaan rencana mutu, proses yang berkaitan dengan pelanggan, evaluasi persyaratan berkaitan dengan hasil pekerjaan, desain dan pengembangan, sosialisasi/pelatihan/bimbingan teknis, pengadaan, proses dan pelaksanaan kegiatan, pengendalian sarana monitoring dan pengukuran mengalami peningkatan sebesar $10 \%$ maka kualitas pelaksanaan kegiatan operasi dan pemeliharaan mengalami peningkatan sebesar $4,49 \%$ dan sebaliknya, penurunan pada penyediaan rencana mutu, proses yang berkaitan dengan pelanggan, evaluasi persyaratan berkaitan dengan hasil pekerjaan, desain dan pengembangan, sosialisasi/pelatihan/bimbingan teknis, pengadaan, proses dan pelaksanaan kegiatan, pengendalian sarana monitoring dan pengukuran sebesar $10 \%$ maka kualitas pelaksanaan kegiatan operasi dan pemeliharaan akan mengalami penurunan sebesar $4,49 \%$.

Variabel pengukuran, analisis dan perbaikan $\left(\mathrm{X}_{3}\right)$

Nilai koefisien regresi variabel $\mathrm{X}_{3}$ menunjukkan nilai sebesar 1,210 artinya bahwa setiap kenaikan variabel $\mathrm{X}_{3}$ sebesar $1 \%$ maka variabel $\mathrm{Y}$ akan naik sebesar $1,210 \%$ dengan asumsi variabel bebas yang lain dari model regresi adalah tetap. Monitoring dan pengukuran, pengendalian hasil pekerjaan tidak sesuai, dan analisis data mengalami peningkatan sebesar $10 \%$ maka kualitas pelaksanaan kegiatan operasi dan pemeliharaan mengalami peningkatan sebesar $12,10 \%$ dan sebaliknya, penurunan pada monitoring dan pengukuran, pengendalian hasil pekerjaan tidak sesuai, dan analisis data sebesar $10 \%$ maka kualitas pelaksanaan kegiatan operasi dan pemeliharaan akan mengalami penurunan sebesar $12,10 \%$. 


\section{Analisis koefisien determinasi}

Koefisien determinasi menjelaskan variasi pengaruh variabel-variabel bebas terhadap variabel terikatnya. Atau dapat pula dikatakan sebagai proporsi pengaruh seluruh variabel bebas terhadap variabel terikat.

Tabel 7. Hasil uji koefisien determinasi

\begin{tabular}{lcrccc}
\hline Model & \multirow{R}{*}{$\begin{array}{c}\boldsymbol{R} \\
\text { Square }\end{array}$} & $\begin{array}{c}\text { Adjusted } \\
\boldsymbol{R} \text { Square }\end{array}$ & $\begin{array}{c}\text { Std. } \\
\text { Error }\end{array}$ & DW \\
\hline 1 & $0,919^{\mathrm{a}}$ & 0,845 & 0,816 & 2,18779 & 2,523 \\
\hline
\end{tabular}

Berdasarkan hasil analisis diperoleh nilai adjusted $R$-square yang besarnya 0,816 , menunjukkan bahwa proporsi pengaruh variabel bebas pengelolaan sumber daya $\left(\mathrm{X}_{1}\right)$, penyelenggaraan kegiatan $\left(\mathrm{X}_{2}\right)$, dan pengukuran, anaisis dan perbaikan $\left(\mathrm{X}_{3}\right)$ terhadap variabel kualitas pelaksanaan kegiatan operasi dan pemeliharaan (Y) sebesar $81,60 \%$. Artinya, secara simultan dapat diketahui masing-masing variabel dependent (bebas) memiliki pengaruh secara bersama-sama terhadap variabel independent sebesar $81,60 \%$ sedangkan sisanya $8,40 \% \quad(100 \% \quad-81,60 \%)$ dipengaruhi oleh variabel lain yang tidak ada di dalam model regresi linier ini.

\section{Analisis uji F (secara simultan)}

Uji analisis F secara simultan untuk mengetahui signifikansi pengaruh variabel bebas secara bersama-sama (simultan) terhadap variabel terikat.

Tabel 8. Hasil analisis uji $F$

\begin{tabular}{cccccc}
\hline Model & $\begin{array}{c}\text { Sum of } \\
\text { Squares }\end{array}$ & df & $\begin{array}{c}\text { Mean } \\
\text { Square }\end{array}$ & F & Sig. \\
\hline Regression & 418,217 & 3 & 139,406 & 29,125 &, $000 \mathrm{~b}$ \\
Residual & 76,583 & 16 & 4,786 & & \\
Total & 494,800 & 19 & & & \\
\hline
\end{tabular}

Berdasarkan hasil analisis Uji $\mathrm{F}$ diperoleh Nilai $\mathrm{F}_{\text {hitung }}$ (sig.) $0,000<$ dari tingkat signifikansi 0,05 sehingga dapat disimpulkan bahwa model regresi linier yang diestimasi layak digunakan untuk menjelaskan pengaruh variabel pengelolaan sumber daya $\left(\mathrm{X}_{1}\right)$, penyelenggaraan kegiatan $\left(\mathrm{X}_{2}\right)$, pengukuran, analisis dan perbaikan $\left(\mathrm{X}_{3}\right)$ yang secara bersama-sama (simultan) berpengaruh signifikan terhadap variabel kualitas pelaksanaan kegiatan operasi dan pemeliharaan (Y).

\section{Analisis uji T (secara parsial)}

Berdasarkan hasil analisis Uji T (Tabel 6.) dapat diuraikan hal-hal sebagai berikut:

\section{Hipotesis pertama $(\mathrm{H} 1)$}

Hipotesis $\mathrm{H} 1$ dinyatakan bahwa diduga variabel pengelolaan sumber daya $\left(\mathrm{X}_{1}\right)$ secara parsial berpengaruh signifikan terhadap Variabel kualitas pelaksanaan kegiatan operasi dan pemeliharaan (Y). Berdasarkan hasil analisis uji $\mathrm{T}$ dapat diketahui bahwa besarnya nilai $t_{\text {hitung }}$ sebesar 2,559> nilai $t_{\text {tabel }}$ sebesar 2,120 dan tingkat signifikansi sebesar $0,021<0,05$ sehingga didapatkan keputusan menolak Ho dan menerima $\mathrm{H}_{1}$. Hasil pengujian regresi ini dapat disimpulkan mendukung hipotesis $\mathrm{H} 1$ bahwa variabel pengelolaan sumber daya $\left(X_{1}\right)$ secara parsial berpengaruh signifikan terhadap variabel kualitas pelaksanaan kegiatan operasi dan pemeliharaan (Y).

\section{Hipotesis kedua (H2)}

Hipotesis $\mathrm{H} 2$ dinyatakan bahwa diduga variabel penyelenggaraan kegiatan $\left(\mathrm{X}_{2}\right)$ secara parsial berpengaruh signifikan terhadap variabel kualitas pelaksanaan kegiatan operasi dan pemeliharaan (Y). Berdasarkan hasil analisis uji $\mathrm{T}$ dapat diketahui bahwa besarnya nilai $t_{\text {hitung }}$ sebesar $2,139>$ nilai $t_{\text {tabel }}$ sebesar 2,120 dan tingkat signifikansi sebesar $0,048<0,05$ sehingga didapatkan keputusan menolak Ho dan menerima $\mathrm{H}_{1}$. Hasil pengujian regresi ini dapat disimpulkan mendukung hipotesis $\mathrm{H} 2$ bahwa variabel penyelenggaraan kegiatan $\left(\mathrm{X}_{2}\right)$ secara parsial berpengaruh signifikan terhadap variabel kualitas pelaksanaan kegiatan operasi dan pemeliharaan (Y).

\section{Hipotesis ketiga (H3)}

Hipotesis H3 dinyatakan bahwa diduga variabel pengukuran, analisis dan perbaikan $\left(\mathrm{X}_{3}\right)$ secara parsial berpengaruh signifikan terhadap variabel kualitas pelaksanaan kegiatan operasi dan pemeliharaan (Y). Berdasarkan hasil analisis uji T dapat diketahui bahwa besarnya nilai $t_{\text {hitung }}$ sebesar 4,429> nilai $t_{\text {tabel }}$ sebesar 2,120 dan tingkat signifikansi sebesar $0,000<0,05$ sehingga didapatkan keputusan menolak Ho dan menerima $\mathrm{H}_{1}$. Hasil pengujian regresi ini dapat disimpulkan mendukung hipotesis $\mathrm{H} 3$ bahwa variabel pengukuran, analisis dan perbaikan $\left(\mathrm{X}_{3}\right)$ secara parsial berpengaruh signifikan terhadap variabel kualitas pelaksanaan kegiatan operasi dan pemeliharaan $(\mathrm{Y})$.

\section{Uji dominan}

Untuk mengetahui variabel yang paling mendominasi atau paling berpengaruh diperoleh dari nilai unstandardized coeffiecient masing- 
masing variabel. Berdasarkan Tabel 6 di atas, dapat diketahui bahwa nilai koefisien regresi terbesar dimiliki oleh variabel pengukuran, analisis dan perbaikan $\left(\mathrm{X}_{3}\right)$ yaitu 1,210 dengan t hitung sebesar 4,429. Jadi dengan demikian variabel pengukuran, analisis dan perbaikan $\left(\mathrm{X}_{3}\right)$ yang paling dominan dalam mempengaruhi variabel kualitas pelaksanaan kegiatan operasi dan pemeliharaan $(\mathrm{Y})$.

\section{Pembahasan hasil penelitian}

Hasil penelitian ini menunjukkan hal yang sama dengan pendapat Oakland (1997) bahwa program peningkatan kualitas yang baik harus berbasis pada proses dan tidak hanya mengandalkan pada inspeksi akhir. Untuk setiap proses yang ada di suatu proyek konstruksi sebaiknya dilakukan suatu perhitungan tingkat kemampuan untuk masingmasing proses karena ini merupakan indikator yang baik untuk mengukur tingkat efektifitas proses tersebut untuk dapat menghasilkan suatu produk terhadap target yang telah di tetapkan.

Kegiatan operasi dan pemeliharaan merupakan pekerjaan konstruksi melalui kegiatan perawatan, perbaikan, pencegahan dan pengamanan yang dilakukan secara terus menerus. Kualitas pekerjaan operasi dan pemeliharaan harus sesuai dengan yang disyaratkan atau distandarkan. Suatu produk memiliki kualitas apabila sesuai dengan standar kualitas yang ditentukan. Standar kualitas meliputi material, proses produksi dan produksi jadi (Nasution, 2005). Peningkatan kualitas pelaksanaan suatu pekerjaan konstruksi merupakan suatu proses produksi yang harus sesuai dengan standar kualitas pelaksanaan yang telah ditentukan.

Berdasarkan hasil uji regresi hipotesis (uji simultan) menunjukkan bahwa variabel independent yang terdiri dari pengelolaan sumber daya $\left(\mathrm{X}_{1}\right)$, penyelenggaraan kegiatan $\left(\mathrm{X}_{2}\right)$, pengukuran, analisis dan perbaikan $\left(\mathrm{X}_{3}\right)$ secara bersama-sama berpengaruh signifikan terhadap variabel kualitas pelaksanaan kegiatan operasi dan pemeliharaan (Y). Hasil uji regresi hipotesis ini dapat disimpulkan bahwa penerapan sistem manajemen mutu berpengaruh positif dan signifikan terhadap peningkatan kualitas pelaksanaan pekerjaan operasi dan pemeliharaan pada tugas pembantuan operasi dan pemeliharaan D.I. Kedung Asem dan D.I. Bodri.

Hasil penelitian ini hanya mencakup pada 2(dua) lokasi penelitian yaitu D.I. Kedung Asem dan D.I. Bodri, sehingga hasil penelitian ini tidak dapat digenarilisir sebagai hasil kesimpulan umum untuk menjawab latar belakang kondisi operasi dan pemeliharaan jaringan irigasi dalam skala nasional.

\section{Kesimpulan}

Berdasarkan analisis dan hasil pembahasan, maka dapat disimpulkan beberapa hal yang sekaligus menjadi tujuan dari penulisan tesis ini, yaitu:

1. Identifikasi penerapan sistem manajemen mutu meliputi penilaian responden terhadap indikator variabel pengelolaan sumber daya $\left(\mathrm{X}_{1}\right)$ yang dipersepsikan pada kategori cukup baik, variabel penyelenggaraan kegiatan $\left(\mathrm{X}_{2}\right)$ dan variabel pengukuran, analisis dan perbaikan $\left(\mathrm{X}_{3}\right)$ dipersepsikan pada kategori baik. Penilaian responden terhadap indikator variabel pengelolaan sumber daya $\left(\mathrm{X}_{1}\right)$ masih memiliki persepsi yang rendah, dikarenakan masih perlu peningkatan pada indikator penyediaan anggaran, kemampuan sumber daya manusia melalui pelatihan, ketersediaan prasarana dan sarana seperti gedung, ruang kerja, peralatan, transportasi yang dibutuhkan, dan ketersediaan lingkungan kerja sesuai dengan persyaratan mutu yang terkait persyaratan keamanan, kesehatan, keselamatan dan kenyamanan.

2. Identifikasi kualitas pelaksanaan kegiatan operasi dan pemeliharaan yang meliputi penilaian responden terhadap indikator variabel kualitas pelaksanaan kegiatan operasi dan pemeliharaan (Y) dipersepsikan pada kategori baik. Penilaian responden terhadap indikator perbandingan kesesuaian petunjuk operasional kegiatan dengan keadaan lapangan masih memiliki persepsi yang rendah dari responden bila dibandingkan penilaian responden terhadap indikator variabel lainnya. Indikator variabel penyiapan rencana kerja dan sosialisasi kegiatan dipersepsikan pada kategori baik dengan nilai rata-rata persepsi responden yang tinggi. Hasil penilaian indeks kinerja sistem irigasi pada Daerah Irigasi Kedung Asem dan Daerah Irigasi Bodri adalah berkinerja baik.

3. Berdasarkan hasil analisis uji F (uji simultan) menunjukkan bahwa variabel pengelolaan sumber daya $\left(\mathrm{X}_{1}\right)$, penyelenggaraan kegiatan $\left(X_{2}\right)$, pengukuran, analisis dan perbaikan $\left(X_{3}\right)$, secara bersama-sama berpengaruh signifikan terhadap kualitas pelaksanaan kegiatan operasi dan pemeliharaan (Y). Hasil uji simultan tersebut mendukung hipotesis penelitian ini, bahwa penerapan sistem manajemen mutu berpengaruh positif dan signifikan terhadap peningkatan kualitas pelaksanaan pekerjaan operasi dan pemeliharaan pada tugas pembantuan operasional dan pemeliharaan D.I. Kedung Asem dan D.I. Bodri. 


\section{Ucapan Terima Kasih}

Pada kesempatan ini penulis ingin mengucapkan terima kasih kepada pihak-pihak yang telah membantu dalam penelitian ini:

1. Ir. M. Agung Wibowo MM, MSc, Phd selaku pembimbing I, memberikan arahan dan masukan pada penelitian.

2. Dr. Ir. Pranoto SA, Dipl. HE, MT, selaku Pembimbing II, memberikan arahan dan masukan pada penelitian.

3. Ir. Indah Sulistyowati, M.Si selaku Kepala Balai PSDA Jratung Tuntang yang memberikan masukan dan saran yang positif dalam penelitian ini.

4. Pegawai di Balai PSDA Jratung Tuntang yang telah memberikan data dan bersedia sebagai responden pada penelitian ini.

5. Pihak-pihak lain yang tidak dapat disebutkan satu per satu.

\section{Daftar Pustaka}

Direktorat Pengelolah Air, 2010. Kerusakan Jaringan Irigasi, Pustaka Kementerian Pertanian, Indonesia.

Malhotra, Naresh K., 1999. Marketing Research: An Applied Orientation, Third Edition, Prentice Hall International Inc, New Jersey.

Menteri Pekerjaan Umum, Peraturan Menteri Nomor 33 Tahun 2015 tentang Tugas Pembantuan Operasi dan Pemeliharaan, Indonesia.
Menteri Pekerjaan Umum, Peraturan Menteri Nomor 01 Tahun 2014 tentang standar Pelayanan Minimal Bidang Pekerjaan Umum dan Tata Ruang, Indonesia.

Menteri Pekerjaan Umum, Peraturan Menteri Nomor 04 Tahun 2009 tentang Sistem Manajemen Mutu, Indonesia.

Menteri Pekerjaan Umum, Peraturan Menteri Nomor 32 Tahun 2007 tentang Pedoman Operasi dan Pemeliharaan Jaringan Irigasi yang menetapkan Indeks Kinerja Sistem Irigasi, Indonesia.

Nasution, 2005. Total Quality Management, PT Gramedia Pustaka Utama, Jakarta.

Nazir, 1999. Metode Penelitian, Cetakan Ketiga, Ghalia Indonesia, Jakarta.

Novitasari, A., Nyoman, N., 2003. Pengaruh Stress Kerja terhadap Motivasi dan Kinerja Karyawan PT. H.M Sampoerna, Tesis tidak dipublikasikan, Universitas Airlangga, Surabaya.

Oakland, Jhon S., tt, 1997. Total Quality Management, $2^{\text {nd }}$ edition, Ox-frod, butterworthheinneman.

Sugiyono, 2007. Metode Penelitian Bisnis, CV Alfabeta, Bandung. 